\title{
All Hats and Moustaches: Commemorating and Performing 1916 in 2016
}

\author{
Feargal Whelan \\ UCD Humanities Institute, Ireland \\ feargal.whelan@gmail.com
}

Copyright (c) 2017 by Feargal Whelan. This text may be archived and redistributed both in electronic form and in hard copy, provided that the author and journal are properly cited and no fee is charged for access.

\begin{abstract}
This paper will survey the means employed by various bodies within Ireland to commemorate the 1916 Easter Rising and argue that the various competing events combined to expose paradoxes of attitudes and behaviours at the heart of Irish society, and also interrogated the very methods of traditional commemoration which might be useful when a country revisits histories which are contentious and conflicted. An exhaustive survey is not intended rather it will focus more precisely on the street spectacle of the various parades and participatory events, and on two site-specific theatrical performances which formed part of the official programme. It will also assess the role played by the Abbey Theatre as a crucial central space in both 1916 and 2016, and demonstrate its role in various events.
\end{abstract}

Key Words. Easter Rising, 1916, Centenary, Commemoration, Performance, Abbey Theatre

Resumen. Este artículo versa sobre las conmemoraciones oficiales en Irlanda, celebradas durante 2016, relativas al centenario del Alzamiento de Pascua de 1916. El autor del trabajo argumenta que dichas celebraciones pusieron de relieve las contradicciones existentes en el seno de la sociedad irlandesa actual, al tiempo que impulsaron una reflexión sobre los métodos que tradicionalmente se emplean para recordar eventos del pasado. Sin la intención de ofrecer una panorámica completa de todos los actos conmemorativos celebrados en Irlanda en 2016, este artículo se fija especialmente en algunos desfiles y en destacados actos públicos, incluyendo representaciones teatrales que recrearon los sucesos de 1916. El papel del Abbey Theatre como símbolo del sentimiento imperante durante el conflicto de hace un siglo, y su papel en la sociedad irlandesa de hoy en día, será igualmente analizado.

Palabras clave. Alzamiento de Pascua, 1916, centenario, conmemoración, representación, Abbey Theatre

2016 provided a momentous year for commemoration in Ireland. It marks the one hundredth anniversary of the Easter Rising in which a group of Irish volunteer rebels took control of the centre of Dublin city and declared a republic independent of The United Kingdom of which Ireland was a part. The insurgents survived a fierce military engagement with the British army 
for six days before surrendering. All those involved were jailed and 16 of the leaders were executed. This moment has been regarded as a crucial moment in the cause of Irish freedom and a glorious event in the nation's history. Therefore, its celebration was always going to be an important affair. Yet the moment of the Easter Rising has many contradictions attached to it, and equally, any attempt to commemorate it has shown up these difficulties and coincidentally exposed the enormous and continuing paradoxes at the centre of Irish political and cultural life in the twenty first century. The coming of 2016 and with it the anniversary of the events of 1916 as they affected Ireland provided the Irish government with, at once, an opportunity but also a palpable problem in relation to how it should mark the centenary. It was an opportunity to celebrate the Easter Rising which, it is generally accepted, led eventually to the foundation of the independent state of Ireland in 1921, and it was an opportunity to re-examine those contentious events from a vantage point which benefitted from the distance of passed time with the self-confidence derived from a modern, wellestablished nationhood. Yet it also presented the problem of selecting what was to be officially commemorated. The Easter Rising may be one of the founding myths of the Irish nation but 1916 also witnessed the Battle of the Somme, not only the modern founding myth of Ulster Protestant resistance but a ferocious World War One engagement in which thousands of Catholic Irishmen fought, many of whom were committed Irish Nationalists of varying degrees, and whose experience had effectively been erased from official memory. By focusing on the various events, scrutiny of the aims of objectives of those who had fought would naturally be addressed and how they might have been achieved or denied brought to account. Given the difficult history, especially with the fractious events in Northern Ireland in the intervening years, with its current hard-won, if fragile, peace, it was a rational fear that stirring up those moments might have an effect of restoring tribalist behaviour among the communities involved.

The need for the commemoration of specific historic events is apparent within broad Irish culture and in itself throws up a contradiction between what it is that is being commemorated and the contemporary reason for the commemoration in the first place. As Emilie Pine observes, "The Irish cultural obsession with the past is an imperfect form of remembering" (2011:16) suggesting that in the process of commemorating, until now at least, it seems unclear if the actual historic event is the one being brought to mind. Declan Kiberd further illuminates this inherent contradiction by arguing that there is a tension between celebrating the past at the expense of the present in how history is recalled in Ireland: "The penchant for commemoration is a tell-tale sign of a community which, pained by the process of unequal development, has difficulty in adjusting to modernity. Yet the nationalism to which it appeals is modern in the sense that it rejects a dynamic traditionalism and seeks to abort the historical process" (1996: 294). An understanding of the latent problems in previous manifestations of Irish commemoration, as evidenced in these critiques, may well have informed the decision taken by the Government in 2012 to fix a shape on the official events which would mark the various centenaries which were to occur over the following years, beginning with the enactment of the Home Rule Bill in 1912 and concluding with the founding of the Free State in 1922. An expert group comprising ten historians was appointed to aid an all-party committee of politicians to provide for "the development of access to historical records and primary sources from the time period, and for working with local and national cultural bodies to bring forward a series of exhibitions and public discussions" (Decade of Centenaries 2012). A clear declaration from the group relating to the evenhandedness and inclusivity which would underpin all events suggests strongly that there was a belief that past commemorations had failed to be inclusive of the whole of the population and that they may have served to inflame subversion within the state. It is worth quoting the statement in full: 
The commemoration will be measured and reflective, and will be informed by a full acknowledgement of the complexity of historical events and their legacy, of the multiple readings of history, and of the multiple identities and traditions which are part of the Irish historical experience. There must be full acknowledgement of the multiple identities and traditions which are part of the overall story and of the different ideals and sacrifices associated with them. Official events must within reason be inclusive and non-partisan, but the State should not be expected to be neutral about its own existence. The aim should be to broaden sympathies, without having to abandon loyalties, and in particular recognising the value of ideals and sacrifices, including their cost. (Decade of Centenaries 2012)

This detailed declaration suggests a certain nervousness on behalf of the State not to be overtly triumphalist or even celebratory, and seems to have been tempered by the fiftieth anniversary commemorations of 1966 in which the events were to be celebrated through "reenactment" in a grand pageant at Croke Park Stadium which was seen to project a particularly uncritical view of the insurrection and tended to focus on the heroism of the seven signatories of the Proclamation of the Republic, elevating their status at the expense of others involved (Roche 2007; Daly 2007). As a consequence, it was felt that the 2016 celebrations should be "inclusive" of all traditions, by which it meant to include those who had also opposed the Rising, or had been perceived as doing so. Thus, the aims of the expert board outlined their view of how to appeal to the various interests by implicitly expressing their fears for what might arise from a lack of even-handedness:

The goal of inclusiveness is best achieved, not by trying for an enforced common interest or universal participation in commemorations for events such as the 1916 Rising or the opening of the parliament in Northern Ireland, but by encouraging multiple and plural commemorations which remember the past while ensuring, as far as possible, that the commemoration does not re-ignite old tensions. (Decade of Centenaries 2012)

The result of this approach was a greater emphasis than before on the events of the First World War from 1916 which had involved the greater number of Irishmen than the events on Irish soil. Inevitably, the protracted Battle of the Somme became a recurring feature. This was a novel approach as evidenced by Emilie Pine's observation as recently as 2011:

Within a nationalist context the Irish soldiers of the Great War have often been forgotten in the larger purpose of remembering Easter 1916, while in a unionist context the entirety of experiences of the Great War has been refined into the remembrance of the Battle of the Somme, July 1916. While these are two very different and, indeed, mutually exclusive mythologies, they emerge from a very similar decision to construct and commemorate the past in political terms. (2011: 127)

\section{Rehearsing the Rising}

There are many contradictions at the heart of the events of 1916 in Ireland. For various reasons, the uprising was not a particularly popular revolution when it initially happened. Firstly, it took place in the middle of World War I when around two hundred thousand Irishmen were fighting for the British Army in the trenches of France and Belgium. Many 
these men had left poor families behind sustained only by what the men earned as soldiers. Any attack on the British Empire was felt by these dependents as an attack on them and on their incomes.

Even within the group of Irish volunteers who were to carry out the rebellion, only a fraction actually took part because of a disagreement among the leadership on the day. Although it was planned and executed as a military operation, and most of the leadership prepared for a victory in the short term, in reality it was a military disaster as the soldiers occupied large important buildings which they could never defend properly. While it has to be admitted that among the leaders there were those who intended the action to achieve a certain military success, in the eyes of Pearse, in particular, the greater achievement was to be had in the impact of action itself and even in its inevitable failure. For Pearse, the plan had as much to do with being a theatrical performance which would be doomed to failure rather as it had a battle which would have a chance of success.

Another great contradiction, of course, is that 1916 is not even the actual date of Irish independence. Although it certainly was a catalyst on the path to independence, this was not finally achieved until 1922, following two years of a guerrilla war which took place in various locations throughout the country. Even then, what resulted was the independence only in a part of the country and the creation of a separate Northern Ireland, which remained part of the United Kingdom leading to subsequent decades of violence and repression.

Yet 1916 has long been regarded as the high moment of Irish history, in which independence from the British finally began. So, it was long accepted that the one hundredth anniversary of the event would have to be commemorated nationally. But it was also understood that there were dangers in celebrating it without question given its contradictory nature. There were fears that simplistic interpretations of the Rising would be used by certain republican politicians to gain popular support throughout the country. Those nationalists in Northern Ireland who had endured a thirty-year violent struggle for a break with Britain had always regarded 1916 as a supreme moment, and had drawn on its legend to give legitimacy to their own struggle. It was obvious that their means of celebration would differ from the State's version and would reflect a very different interpretation of history.

What emerged was several very different stories and interpretations of 1916 being played out across Dublin in April of 2016 all in the name of commemorating the same events of Irish history. But in reality, the variety of approaches all seemed to demonstrate how much people could not agree about what had actually happened and what it all meant in a new Ireland. However, if the substance of the narrative could not be agreed upon, the manner through which various groups displayed their part in the commemoration was remarkably similar. Common to almost all public engagements were an unashamed theatricality and a desire to dress up.

The events of 1916 may have had a deeply theatrical nature, and I will assess this later, but this very fact alone cannot seem to account for the willingness for such a large cross section of the population to put on approximations of volunteer uniform, however inaccurate, or appear in vague replicas of generic Victorian dress. Even within the official commemorations, the emphasis on military ceremonial drew attention to the pageantry of parade, uniform and flags, which in turn was replicated by various paramilitary parades of various unofficial, irregular groups.

\section{Playacting or merely dressing up?}

The central event of the official State celebration consisted of a military spectacle and a solemn honour of the dead. On Easter Monday, a parade was held in Dublin in which "over 3500 members of the Defence Forces, along with 78 vehicles, 17 aircraft and 5 equitation 
School horses" took part, comprising "one of the biggest ceremonial events [which] the Defence Forces ha[d] ever been involved in" (Óglaigh na hÉireann 2016). To provide a civilian parallel, RTÉ, the national broadcaster, organised a street event which invited the general public to partake in a celebration which would include "live theatre, music, poetry, portraiture, aerial shows, games, workshops, food, film screenings, classic car shows, Easter week 1916 re-enactments, and several free walking tours departing from locations around the city" (Ireland 2016b). Those taking part were invited to wear the fashion of the time, and many broadcasters were depicted dressed up, frequently with false moustaches. The unofficial celebrations from the various Republican groups involved marches by men in paramilitary uniform, or parades by those re-enacting the Rising itself. In these cases, the parallels with the State's military parade were unavoidable. The only difference was in the style of uniform used by the various paramilitaries or their sympathisers. An aggressively macho use of generic camouflage fatigues with combat jackets and sunglasses was combined with approximations of what was understood to be 1916 volunteer uniforms. Consequently, putting on costume seemed to be the most common, public way of celebrating the event. The inherent difficulties raised by recalling such contentious events were highlighted by the paradox of the overt uniformed militarism of the State's recall, the hyper-aggressive grotesque imitation of such a display by the various republican groups, and the inanely comic display of ill-defined nostalgia by the national broadcaster and by thousands of ordinary citizens. There was a danger that the attempt at inclusivity might become mere farce as slouched hats and false moustaches became ubiquitous, even becoming available as cheap fancy dress costumes.

What became apparent, ironically, was the understanding that theatrical performance was central to everybody's idea of commemoration. This may have appeared odd at first, and yet it seems rather appropriate, as the original revolution was so heavily influenced by performance through its links to the Irish Dramatic movement of the late nineteenth century. The Rising itself drew as much power from its theatricality as it did from its physical force. As Tony Roche observes, he event was "constructed along theatrical line, with great attention to costuming, staging, etc., and with [Pádraig] Pearse's primary role in promoting the Rebellion being that of scriptwriter rather than active participant" (2016: 304). Although it might be argued that this view subordinates Pearse's role as willing sacrificial figure in a physical fight, it is undeniable that the needs of military strategy were less privileged than the concerns of how the insurrection would play out as spectacle and event. The choice, for example, of the GPO in O'Connell Street as the centre of command for the entire operation, housing the two senior commanders, James Connolly and Pearse, was a military folly, yet as a most visible and symbolic location, its impact could not have been surpassed. Indeed, given that the strategy seems to have been decided on maximising the perception of the fighting itself, rather than on the needs of achieving outright victory, it is frequently argued that the whole event should be read as performance rather than battle. As Ben Levitas argues, the Rising was "staged as [a] production" and could be read as "part mystery play, part melodrama, part avant-garde provocation" (224: 224). Pearse, who maintained that the role of the insurrection was to produce a sacrifice to inspire the Irish people, never considered a military victory to be achievable or even desirable, and was motivated to make the events as spectacular as possible rather than as militarily successful as possible. It is unsurprising that Michael Collins, a later military leader, would remark: "Looking at it from the inside (I was in the GPO) it had the air of a Greek tragedy about it" (qtd. in Moran 2005:18).

Apart from the prosecution of events on the street at Easter 1916, the environment from which they had developed placed the theatre and the stage in a central position. Among the signatories of the Proclamation of the Republic four of the seven had had plays produced, two of whom, Thomas MacDonagh and James Connolly, had even "rehearsed the rebellion on the Irish stage before they led the troops into the streets of Dublin" (Moran 2005:6). On the 
day of the Rising, among those taking part in the events, eight were members of the Abbey company and the theatre building itself played a central role, as Fearghal McGarry points out "unknown to Yeats, the press on which the Proclamation was reportedly printed had been kept hidden ... under the stage of the Abbey" (2015: 5) where it lay beside the personal rifle of actor Arthur Shields. Kathleen Ni Houlihan (1902), which Yeats later grandiosely fancied had set the whole revolution off, was scheduled to play on the Abbey stage on the very night of the outbreak of the Rising. The actor Seán Connolly who had played in Kathleen on the Abbey only the previous month was the first volunteer casualty of the engagement when he was shot dead in Dublin's City Hall. In all, the stamp of Dublin's theatre was imprinted on the events, from the playbill appearance of the Proclamation of the Republic, to the rehearsal of the "manoeuvres" over the weeks preceding Easter, to the actual prosecution of the tactics of the battle, with its emphasis on securing and defending visible, monumental buildings, with the headquarters in the GPO on the main street of the city.

\section{Observe the Sons of Ulster Marching Towards the Somme}

The very theatrical nature of the 1916 events meant that a particular importance would be granted to those plays produced for the commemoration. In 1966, the official commemoration committee had advised that any production of a Seán O'Casey play "would not be in helping with the spirit of the occasion" (qtd. in Daly 2007: 19), but in 2016 any unease had lifted as a new version of The Plough and the Stars (1926) was produced on the Abbey stage before embarking on a national and international tour. Among other theatrical pieces to commemorate the events, ANU Productions presented the new play Rebel, Rebel set during Easter week, and acting as a companion piece to their production of Pals (2014) which told the story of the Dublin Fusileers at the Battle of Gallipoli. UCD mounted a speciallycommisioned and site specific piece, Signatories, which was presented in Kilmainham Gaol before touring other venues. In the spirit of the even-handedness evoked by the official committee of 2016, the Abbey Theatre also revived Frank McGuiness's Observe the Sons of Ulster Marching Towards the Somme (1985), to tour Ireland and the United Kingdom, as well as perform on the site of the original battle which it commemorates. In assessing the impact of the works on the year of commemoration I will examine Signatories and Observe the Sons of Ulster together, as they deal with the opposite sides of the conflict and because they have contrasting performance histories.

McGuiness's play depicts the experiences of eight young Ulster Protestants who enlist in the army in 1916. They are shown at their initial meeting on joining up, on a subsequent period of leave from the fighting in Belgium and finally, as they prepare for their final engagement at the Battle of the Somme, in which all but one of them will die. The play is framed by the monologue of the sole survivor as he remembers the events from a distance of seventy years. It celebrates the humanity and courage of the individuals and powerfully highlights their commitment to the idea, and ideal, of an Ulster which is wholly British and separate from Ireland. The fight in which they take part in Belgium assumes the nature of the fight for their own soil of Ulster.

In Dublin in 1985, the idea of such a sympathetic and heroic portrayal of Ulster loyalism and unionism did not immediately seem attractive. However, the play proved to be an enormous success, transferring from the small stage of the Peacock to the main stage at the Abbey almost immediately. Its status was elevated by the replacement of the lead character of Old Piper with the internationally renowned film and stage actor Ray McAnally. When the play was revived in 1994, against the backdrop of the paramilitary ceasefires in Northern Ireland which eventually led to the current peace, leading loyalists were invited to the opening night, as Pine observes, "to reach out" to an opposing side (2011: 147). The Lord Mayor of 
Dublin, John Gormley, attended in his mayoral chain, paradoxically bearing the image of the loyalist icon King William of Orange, Protestant hero of the Battle of the Boyne, and the closest one might come to a Protestant saint. Gormley has described the palpable sense of emotion among the northern guests, recalling "grown men, hardened men, in tears" (Whelan 2000).

The 2016 revival intensified the resonance of the play when it was performed at Thiepval, the site of the original engagement on which the play was based. Recollecting that he had originally written it as an act of commemoration in 1985, McGuinness observed that at that time the seventieth anniversary, which he was celebrating, "was barely noticed" and noted that "the whole idea of commemoration has become much more popular. People are more willing to learn from the past, but also to say, "What courage" (Marlowe: 2016). Echoing the central thrust of the State's official even handedness, the Irish Ambassador added, somewhat smugly, "everyone else did military commemorations ... ours was the only cultural reaction" (Marlowe 2016).

What Frank McGuinness was pointing out was that in 1985 there was no appetite for commemoration of the Somme by the Irish people, and that he found himself deliberately interrogating this act of deliberate forgetting. The Belgian performance of the play acted as a very different type of commemoration from its two previous productions. By virtue of its iteration as an Abbey Theatre production it bore the imprimatur of the national theatre. Yet it was a co-production with three United Kingdom companies: Headlong, Citizens Theatre and Liverpool Everyman \& Playhouse, and used an English director thereby creating an immediate sense of sharing any historical resonance which may have arisen and fulfilling the sense of evenhandedness so apparent in the State's mission statement.

\section{Signatories}

To offer a comparison with McGuinness's play it would be instructive to assess the impact of another site-specific performance. As part of its contributions to the centenary commemoration, University College Dublin commissioned eight of its noted alumni to write a monologue relating to the seven signatories of the Proclamation and one other significant figure. The production was directed by Patrick Mason, the director of the original Observe the Sons of Ulster in 1985, and was produced as a promenade performance inside Kilmainham Gaol, the site of the executions of those condemned in the Rising, from the 22-27 April. The authors chosen were Emma Donoghue, Thomas Kilroy, Hugo Hamilton, Frank McGuinness, Rachel Fehily, Éilís Ní Dhuibhne, Marina Carr and Joseph O’Connor. Each monologue provided a reflection on the character of the individual portrayed and his or her part in the Rising. In the main, each consisted of a portrayal of a personal reflection by each as he awaited execution in the condemned cell. The exceptions were Ní Dhuibhne's "Seán Mac Diarmada" in which Min Ryan, a friend of the executed man, told a story of visiting him on the night before his execution; Emma Donoghue's "Elizabeth Farrell" which related the eyewitness account of the woman who had been central to the activities in Easter week, from acting as a nurse in the GPO to carrying orders from the leaders to the various garrisons, and finally accompanying Patrick Pearse his eventual surrender; and Hamilton's "James Connolly" which avoided any direct engagement with the figure in question by depicting the story of a first generation Irishwoman living in Birmingham.

This production echoed much of the impact of the Abbey's performance of Observe the Sons of Ulster at the Somme by virtue of its location. The performance took place in the fading evening light in the Main hall of Kilmainham Gaol, a site which has barely changed since 1916, and when the shots of execution were heard from beyond the performance space, they appeared to come from the prison's Stonebreakers' Yard, the actual site of the 
executions. Yet there was also an echo of the 1985 production of McGuinness's play in many ways as the audience were forced to confront a different view of a previously understood history. There is a sense in which each of the authors in Signatories was attempting to demonstrate a more complicated portrait of those who had taken part, and certainly they were interested in confronting the hagiographic representation which had become commonplace in certain parts of political ideology and which were the norm in the fiftieth anniversary celebrations in 1966. Consequently, Kilroy's Pearse is a figure tormented as much by his upbringing and a sense of failing an overbearing father as he is a visionary politician and soldier. Donoghue's Farrell celebrates the heroism of the women who took part but is sanguine about the casual misogyny of the volunteers. The most complicated depiction is O'Connor's Joseph Mary Plunkett which illuminated the contradictions of the Rising in one portrait. Plunkett was an English public school-educated son of a wealthy family who lived in a suburban Dublin mansion. He speaks in the manner of his class: "Daddy was a property developer ... Mummy had taken a lease on Larkfield Manor in Kimmage profonde" (O'Connor 2016: 108; 110) and seems to portray a certain amused detachment when describing the "manoeuvres" which the volunteers held on the family lawn. Yet his tone turns sharply, confronting the audience directly: "Don't ever dare to criticize those people, not to me. You had three meals today. They had nothing. But nothing" (2016: 111). In the end, the effect of the performances as a whole reinforced the tone which was hoped for in the commemoration mission statement by drawing attention to the sacrifice and courage of all those involved, while acknowledging certain difficulties: Clarke is unrepentant in his singlemindedness and belief in the absolute necessity for violence, Ceannt is conflicted by having killed a man and cannot reconcile it with his aspiration.

As with the Belgian performance of Observe the Sons of Ulster, Kilmainham Gaol's staging of Signatories derived a huge amount of its impact from its location. But it also challenged the audience's possibly pre-conceived ideas in relation to the individuals involved. It neither elevated them unthinkingly nor demonized them without redemption.

\section{WTF?}

As previously mentioned, The Abbey Theatre's choice of programme for the centenary drew inevitable interest yet its greatest contribution was the inadvertent creation of one of the most interesting cultural/political events of the year. Given its centrality to the Rising and its status as cultural monolith, it was generally felt that the theatre's centenary programme should reflect the state of the nation in some way, accommodating the national narrative as it stood now, one hundred years after the events in which it was so centrally involved. When the announcement of the programme was made, it was felt that the proposed list of ten plays was possibly a little conservative and maybe a little safe, but overall there were few complaints. However, within a very short period, a freelance set-designer called Lian Bell had pointed out that in the whole programme, only one work was written by a woman, and even that was a play for children. Of the rest of the programme, only two of the plays were to be directed by women.

In itself, the fact that women had been overlooked was nothing new. Although a huge number of actors, writers, directors and other practitioners are women, it was usual that they never seemed to get receive the same, proper recognition. The Artistic Director of the Abbey, Fiach MacConghaill, generally viewed as a liberal, innovative type, failed to see the problem and claimed that as he was personally blind to sexism he could not be accused of sexist choices. The inequality that his choices represented did not seem, to him, to be out of the ordinary so that what happened next was wholly unexpected and demonstrated a genuine revolutionary spirit, worthy of 1916. 
Very quickly, through social media and through a couple of articles in the newspapers, an enormous energy and discussion developed over the issue, under the banner "Waking the Feminists" and using the hashtag \#WTF, expressing the incredulity of the women in the theatrical industry. On November 12 2015, the Abbey Theatre provided its stage space for a debate to take place surrounding all issues regarding women in the theatre. What emerged was an enormous outpouring; a collection of personal stories about how women were treated within Irish Theatre, not being taken seriously as artists, being refused roles because of their appearances, being judged on their age, being forgotten about when they have had children, not being treated equally as technicians and directors, not having plays produced as authors. All of these issues, not just confined to theatre but apparent in everyday life, were galvanized and brought together in one session, in one act of testimony on the very stage of the Abbey theatre on which W.B. Yeats had addressed the audiences of Dublin in times of trouble. The movement gathered momentum with theatre professionals and academics beyond Ireland, in the UK, Europe, and in the USA, gaining high levels of support from actors on social media.

Immediately, the loose collection of individuals became a recognisable force within the Irish theatre environment. Through meetings with all the major theatres and funding organisations in the country, they achieved at least a commitment to gender equality at all levels of work. They have drawn attention to the inequality that exists and have been so vocal that it would be almost impossible for any theatre or organisation to quietly reinforce old norms of sexism without being shown up and exposed to ridicule, with the ultimate threat of the loss of sponsorship or grant funding. The organisation has continued in existence, acting both as a watchdog and sounding board and support system for the original ideals.

The Waking the Feminists movement, because of its spontaneity, its energy and the speed with which it came together and developed, demonstrates for me a replica of the moment of 1916. And for this, at least I see some sort of hope for public action. The fact that it took place in the cultural world, in the very theatre that acted as a forum for the performance of the armed revolution is a powerful reminder that culture matters and that theatre matters, at the very moment when the over-emphasis on the monetarisation of art, and the commercialisation of culture through global capitalism suggests that art has nothing to say. In the spirit of 1916, it was an unruly confrontation of an oppressive regime.

\section{Conclusion}

The events which took place to celebrate, or commemorate, 1916 tended to mirror the intricacies of the original ideals of Rising and indeed of the Great War. In the end, because of the contentious and contended nature of the meaning of the historical happenings, it was never likely that a uniform approach betraying a common set of shared values would emerge. The State's official nervousness may have been well founded, but the fear that the attempts to be as even-handed as possible might lead to a certain blandness have not been borne out. In its opening statement the cheery, inoffensive, but ultimately terrified tone of the State's hopes is abundantly clear: "2016 will belong to everyone on this island and to our friends and families overseas - regardless of political or family background, or personal interpretation of our modern history" (Ireland 2016a). Thankfully, the very difficulties which such a view appears to fear probably allowed for events which turned out to be moving, emotional, thoughtful, bizarre and irreverent. The centrality of performance to both the street celebrations and the innovative staged productions echoed the crucial role of the theatre in the original insurrection and the \#WTF demonstrated how crucial a space of the Abbey Theatre, whether it intended to or not, continues to occupy after all. The reclamation of forgotten figures of the time, particularly women involved in the Rising, such as Margaret Skinnider or Kathleen Lynn, and complicated men connected with the Great War, such as Thomas Kettle or Emmet Dalton, has 
deepened the national historical narrative and at least raised debate. The success in participation in unofficial and popular events, such as the "Reclaim 1916" parade, which was organised by a collection of artists and singers and which drew 40,000 to its event on 24 April, suggests a rediscovery of street protest, and street theatre, as a means of engagement and possible resistance. Although there may have been a conservatism on the part of the state in thinking about how to commemorate 1916, born out of concerns of fomenting antagonism, the most significant legacy of the year's events may be seen however, in a return to street demonstration as a form of political resistance. The adoption of the mass rally by those protesting against water charges, those on both sides of the debate on abortion in the state, and even by those wishing to promote a counter argument to official 1916 commemoration. In the end, the scrupulous even-handedness which seems to have underpinned the focus of the commemorative events may have released the original spirit of the Rising, whether it was intended or not, and allowed the public the means of protest and resistance which 1916 encapsulates.

\section{Works Cited}

Daly, Mary E. 2007. "Less a commemoration of the actual achievements and more a commemoration of the hopes of the men of 1916". 1916 in 1966: Commemorating the Easter Rising. Eds. Mary E. Daly \& Margaret O’Callaghan. Dublin: Royal Irish Academy Press. 18-85.

Decade of Centenaries. www.decadeofcentenaries.com/about [retrieved: 15/08/2016]

Ireland. 2016a. www.ireland.ie/about [retrieved: 10/08/2016]

2016b. www.ireland.ie/news/irelands-largest-ever-public-celebration-takes-overdublin-city-tomorrow [retrieved: 01/09/2016]

Kiberd, Declan. 1996 (1995). Inventing Ireland: The Literature of the Modern Nation. London: Vintage Books.

Levitas, Ben. 2002. The Theatre of Nation: Irish Drama and Cultural Nationalism 18901916. Cambridge: Cambridge University Press.

Marlowe, Lara. 2016. "Observe the Sons of Ulster re-enacted in Thiepval". Irish Times. Friday 1 July. http://www.irishtimes.com/news/ireland/irish-news/observe-the-sonsof-ulster-re-enacted-in-thiepval-1.2705949 [retrieved: 13/08/2016]

McGarry, Fearghal. 2015. The Abbey Rebels of 1916: A Lost Revolution. Dublin: Gill \& MacMillan.

Moran, James. 2005. Staging the Rising: Easter 1916 as Theatre. Cork: Cork University Press.

O’Connor, Joseph. 2016. “Joseph Mary Plunkett”. Signatories. Dublin: UCD Press. 103-115.

Óglaigh na hÉireann. 2016. www.military.ie/info-centre/defence-forces-2016/easter-parade2016/ [retrieved: 03/09/2016]

Pine, Emilie. 2011. The Politics of Irish Memory: Performing Remembrance in Contemporary Irish Culture. London: Palgrave.

Roche, Anthony. 2016. "Staging 1916 in 1966: Pastiche, Parody and Problems of Representation". 1916 in 1966: Commemorating the Easter Rising. Eds. Mary E. Daly \& Margaret O’Callaghan. Dublin: Royal Irish Academy Press. 303-332.

Whelan, Feargal. 2000. Interview with John Gormley, 24/04/2000. 
Feargal Whelan holds a BA (Hons), an MA in Anglo-Irish Literature \& Drama and a PhD from UCD. He was awarded a doctorate in 2014 following a thesis entitled Samuel Beckett and the Irish Protestant imagination. He co-organised the annual Samuel Beckett and the 'State of Ireland' conference which was held annually at the UCD Humanities Institute from 2011 to 2013. He has contributed to many international conferences over the years, most notably the MLA Convention in Vancouver in 2015. His work has been published in Journal of Beckett Studies and New Theatre Quarterly, and he has contributed a chapter to Staging Beckett in Ireland and Northern Ireland (London: Bloosmbury, 2016). He was a faculty member of The Samuel Beckett Summer School in TCD for 2016, having been employed by the school since 2013, and has recently been appointed editor of The Beckett Circle, the journal of the International Samuel Beckett Society. 